\title{
Analysis of The Effect of Promotion on the Sales of General Insurance Services at PT. Wahana Tata Insurance
}

\author{
Hero Wirasmara Kusuma \\ Lecturer \\ The University of Faletehan \\ Banten, Indonesia \\ Email: hwirasmara@gmail.com \\ Indonesia
}

\section{$\bar{A}$ R T I C L E I N F O}

Article history: Article

$\begin{array}{ll}\text { Received: } & \text { January } 2021 \\ \text { Revised: } & 20 \text { January } 2021 \\ \text { Accepted: } & 23 \text { January } 2021\end{array}$

DOI: $10.47742 /$ ijbssr.v2n1p3

\section{A B S T R A C T}

This study aims 1) to determine the implementation of promotions carried out by PT. Wahana Tata Insurance, 2) to determine the relationship between promotions and company sales, 30 to find out how much the contribution of promotional costs affects sales results, and 4) how big the role or influence caused by the implementation of promotions to increase sales volume. This study uses primary data from company reports and direct observations of the company's operational activities. The study used a simple linear regression analysis and the regression coefficient significance test. The study results indicate that from the calculation of correlation analysis, the correlation coefficient is positive at 0.87 , which means that the relationship between promotional costs and company sales results is very strong and positive. The calculation of the determinant coefficient analysis shows that promotional activities' contribution to the company's sales results is $75.69 \%$, which means that the contribution of promotional costs is very significant to the company's sales results. From the correlation significance test, the $t$ value is 3.057 , greater than the t-table of 2.353, which means that the relationship between the promotion costs and sales results is strong and significant. And from the calculation of the simple linear regression analysis and the regression coefficient signification test, it is known that the t-count is 3.022, when compared to the t-table is 2.353. This is concluded that $t$ count is greater than $t$-table, which means that there is a strong and significant influence between promotion costs and sales results.

Keywords: Promotion, Company Sales, Sales Volume, Underwriting Income

\section{Introduction}

The economic growth of all the nation's economic activities, which involve humans working and struggling to make ends meet, is a measure of the nation's success in improving its people's standard of living and welfare. As a non-bank financial institution, insurance is felt to contribute to the economy because the potential capital collected through an insurance company is a very large investment and is useful for economic stability and national development. Especially in the General / Loss Insurance business, insurance is essentially an activity of transferring financial risk from the insured as a consumer to the insurer as a producer, which in this case is an insurance company. There is a process of shifting from risk, uncertainty to something certain, namely a sense of security.

PT. Wahana Tata Insurance is one of the insurance companies engaged in the general/loss insurance services business and plays an active role in developing this business in Indonesia. Among others, with its products, Fire Insurance, Marine Cargo Insurance, Motor Vehicle Insurance, Money Insurance, Liability Insurance, etc., PT. Wahana Tata Insurance develops general/general insurance business and competes fairly with other companies engaged in the same field. To achieve marketing goals, promotion can be used to play an important role for PT. Asuransi Wahana Tata as a loss insurance service company. The recognition of these products, services, and services by consumers through promotional activities carried out by the company will automatically increase sales. So that is facing the competition that occurs, the company can concentrate more on developing the best service system, the latest information technology and producing superior products that can meet consumer needs.

\section{Literature Review}

If implemented properly, a promotional activity can influence consumers to decide where and how to spend their income. According to Alma $(2005 ; 181)$ : "The main purpose of promotion is to provide information, attract attention and then give the effect of increasing sales." The company's promotion program is arranged in the promotion plan, a program that is carried out jointly between the Marketing department and other related departments. Programmatic promotional activities are carried out by companies to increase the efficiency of promotional costs and to open opportunities for broad market penetration, with the following objectives:

- Introducing the company profile 
Vol: 2, Issue: 1

January/2021

https://ijbssrnet.com/index.php/ijbssr

DOI: http://dx.doi.org/10.47742/ijbssr.v2n1p3

http://iarpnet.org/

- Introducing corporate identity to the market

- Embedding the company image and positioning the company in the target market

- Commercialization of product brands.

As expressed by Kotler and Armstrong (2005; 182), there are four promotion elements, namely: Advertising, Sales Promotion, Public Relations, and Personal Selling. Likewise, companies in carrying out promotional activities, the company divides them into four main promotion elements.

\section{Advertising}

Companies use advertising or advertising to convey sales messages to the general public, with the aim of:

- The public knows and knows about insurance in general.

- Introducing to the public the company profile.

- As a means of informing insurance service products.

- Offer various types of services that the company can provide.

The advertising media used include:

- Billboards

- Banner

- Advertisement

- Brochure

- Calendar

- Promotional items (souvenirs)

Sales Promotion

Namely, sales promotion activities invite consumers to buy now (sales promotion offers reasons to buy now). Companies that are engaged in general insurance services, were special and more personal business characteristics and characteristics, intense competition, difficulty maintaining clients, and so on, encourage sales promotion to play a more prominent role. This sales promotion activity for the company has a great meaning with the objectives expected to be achieved: a. To attract new clients or buyers. b. Increase the repurchasing power of old clients. c. Increase client loyalty. d. Providing awards for loyal old clients. e. Popularization of insurance package products. f. Give awards to those who support and accelerate business g. Provide incentives for other institutions to continue to help product sales, bring in new clients, and retain old clients, such as brokers, agents, intermediaries, banking, leasing companies, and so on. h. Increase and expand "market share" for the long term.

\section{Public Relations}

By referring to the main principles, which are the company's socio-economic objectives, the company always puts forward creating "good relations" with the community, including a. Carry out blood donation activities b. Carry out social services for disadvantaged communities. c. Make donations for foundations/hospitals. d. Send donations for victims of natural disasters.

\section{Personal Selling}

The sales promotion system with personal selling is the oldest and most important way, especially in the insurance service business, which companies currently use. In this way, the company's marketing staff can create two-way communication between them and their clients or their intermediaries as consumers, and at the same time, act as insurance consultants for clients in need.

\section{Research Method}

This research was conducted at PT. Wahana Insurance Head Office, which is located at Jalan HR Rasuna Said Kav. C4, South Jakarta 12920. The data used are primary data sourced from company reports and direct observations/field research on company activities and secondary data from research literature books, applicable laws, and writings. Others are related to research. The data analysis technique used is descriptive statistical techniques with Correlation Analysis Methods, Determination Coefficient Analysis, Correlation Signification Test, Simple Linear Regression Analysis Method, Regression Coefficient Signification Test.

\section{Results and Discussion}

\section{Income}

\section{Development of Company Sales or Underwriting}

In table 1 below, a summary of the sales or underwriting revenue of the company. In detail, the development of the company's gross premium receipts for each type of insurance (class of business) is presented in table 1:

Table 1. Sales Result / Underwriting Income, Years 2002-2006

\begin{tabular}{|c|r|r|c|}
\hline Years & Underwriting Income & \multicolumn{1}{|c|}{ Ups and Down } & Percentage \\
\hline 2002 & $530,927,211,066.00$ & 0.00 & \\
\hline 2003 & $623,799,763,304.00$ & $92,872,552,238.00$ & 17.49 \\
\hline 2004 & $708,891,152,764.00$ & $85,091,389,460.00$ & 13.64 \\
\hline 2005 & $709,836,240,228.00$ & $945,087,464.00$ & 0.13 \\
\hline 2006 & $723,095,504,938.00$ & $13,259,264,710.00$ & 1.87 \\
\hline Total & $3,296,549,872,300.00$ & $192,168,293,872.00$ & \\
\hline Average & $659,309,974,460.00$ & $38,433,658,774.40$ & 5.83 \\
\hline
\end{tabular}

Source: PT. Wahana Tata Insurance 
Table 2. Development of Gross Premium Receipts, Years 2002-2006

\begin{tabular}{|c|c|c|c|c|c|c|c|c|c|c|}
\hline $\begin{array}{l}\text { Class of } \\
\text { Business }\end{array}$ & 2002 & $\%$ & 2003 & $\%$ & 2004 & $\%$ & 2005 & $\%$ & 2006 & $\%$ \\
\hline Motor Vehicle & 226,295 & 42.62 & 271,467 & 43.52 & 294,181 & 41.50 & 345,713 & 48.70 & 269,886 & 37.32 \\
\hline Property & 218,246 & 41.11 & 241,472 & 38.71 & 288,208 & 40.66 & 210,847 & 29.70 & 299,598 & 41.43 \\
\hline Marine Cargo & 37,644 & 7.09 & 44,469 & 7.13 & 41,894 & 5.91 & 47,394 & 6.68 & 41,936 & 5.80 \\
\hline $\begin{array}{c}\text { Marine \& } \\
\text { Aviation Hull }\end{array}$ & 18,740 & 3.53 & 15,558 & 2.49 & 13,278 & 1.87 & 24,535 & 3.46 & 14,011 & 1.94 \\
\hline Engineering & 4,860 & 0.92 & 9,751 & 1.56 & 11,959 & 1.69 & 26,938 & 3.79 & 21,658 & 3.00 \\
\hline Oil \& Gas & 30 & 0.01 & 16,931 & 2.71 & 15,360 & 2.17 & 27,803 & 3.92 & 54,128 & 7.49 \\
\hline Miscellaneous & 25,112 & 4.73 & 24,152 & 3.87 & 44,012 & 6.21 & 26,607 & 3.75 & 21,878 & 3.03 \\
\hline Total & 530,927 & 100.00 & 623,800 & 100.00 & 708,892 & 100.00 & 709,837 & 100.00 & 723,095 & 100.00 \\
\hline Average & 75,847 & & 89,114 & & 101,270 & & 101,405 & & 103,299 & 37.32 \\
\hline
\end{tabular}

Source: PT. Wahana Tata Insurance

The company's underwriting income has increased every premium of Rp. 709,836 million, there was an increase of Rp. year, which is quite significant, but the percentage of the increase 945 million from 2004. And in 2006, it earned a gross premium tends to decrease. The gross premium in 2002 was Rp. 530,927 of Rp. 723,096 million, there was an increase of Rp. 13,259 million. There was an increase of $66.60 \%$ from the premium in million from 2005.

2001 of $\mathrm{Rp}$. 318,681 million. In 2003, he received a gross premium of Rp. 623,800 million, there is an increase of $17.49 \%$ compared to 2002. In 2004, the gross premium was Rp. 708,891 million. There was an increase of $13.64 \%$ or Rp. Eighty-five has increased every year, but the percentage of increase tends to thousand ninety-one million compared to 2003. In 2005 a gross decrease.

Table 3. Promotion Costs, Years 2002-2006

\begin{tabular}{|c|r|r|c|}
\hline Years & Promotion Costs & Ups and Down & Percentage \\
\hline 2002 & $35,671,463,855.00$ & 0.00 & \\
\hline 2003 & $85,254,242,795.00$ & $49,582,778,940.00$ & 139.00 \\
\hline 2004 & $107,240,692,944.00$ & $21,986,450,149.00$ & 25.79 \\
\hline 2005 & $109,704,995,119.00$ & $2,464,302,175.00$ & 2.30 \\
\hline 2006 & $81,625,828,480.00$ & $-28,079,166,639.00$ & -25.60 \\
\hline Total & $419,497,223,193.00$ & $45,954,364,625.00$ & \\
\hline Average & $83,899,444,638.60$ & $9,190,872,925.00$ & 10.95 \\
\hline
\end{tabular}

Source: PT. Wahana Tata Insurance

In 2002, the company's promotion costs for a year previous year, namely to Rp. 109,705 million. Meanwhile, in amounted to Rp. 35,671 million. In 2003, promotion costs 2006 there was a significant decrease in promotion costs of Rp. increased significantly to Rp. Eighty-five thousand two hundred Twenty-eight thousand seventy-nine million or decreased by fifty-four million during the year, which means an increase of Rp. 25.60\% from the previous year, which was Rp. 81,626 million.

Forty-nine thousand five hundred eighty-three million or an increase of $139 \%$ from the previous year. In 2004, there was an increase to Rp. 107,241 million, compared to the previous year, an increase of Rp. Twenty-one thousand nine hundred eighty-six million or $25.79 \%$. In 2005 there was an increase of Rp. Two thousand four hundred sixty-four million or $2.30 \%$ from the 2002 to 2006 .

3. The Relationship between Promotion Costs and

\section{Company Revenue Results}

Before performing calculations and analysis, Table 4

Table 4. The Percentage of Promotion Costs Against Sales / Income

\begin{tabular}{|c|r|r|c|}
\hline Years & Underwriting Income & Ups and Down & Percentage \\
\hline 2002 & $530,927,211,066.00$ & $35,671,463,855.00$ & 6.72 \\
\hline 2003 & $623,799,763,304.00$ & $85,254,242,795.00$ & 13.67 \\
\hline 2004 & $708,891,152,764.00$ & $107,240,692,944.00$ & 15.13 \\
\hline 2005 & $709,836,240,228.00$ & $109,704,995,119.00$ & 15.45 \\
\hline 2006 & $723,095,504,938.00$ & $81,625,828,480.00$ & 11.29 \\
\hline Total & $3,296,549,872,300.00$ & $419,497,223,193.00$ & \\
\hline Average & $659,309,974,460.00$ & $83,899,444,638.60$ & 12.73 \\
\hline
\end{tabular}

Source: PT. Wahana Tata Insurance

From table 4, it is known that the percentage of the with an average increase in promotional costs each year of comparison of promotional costs for loss insurance products to $12.73 \%$ or Rp. 83,899 million. 
Table 5. Correlation Calculations Promotion Costs (X) and Underwriting Income (Y)

\begin{tabular}{|l|r|r|r|r|r|}
\hline Years & \multicolumn{1}{|c|}{$\mathbf{X}$} & $\mathbf{Y}$ & $\mathbf{X}^{\mathbf{2}}$ & \multicolumn{1}{|c|}{$\mathbf{Y}^{\mathbf{2}}$} & \multicolumn{1}{|c|}{$\mathbf{Y}$} \\
\hline 2002 & 35.671 & 530.927 & $1,272.420$ & $281,883.479$ & $18,938.697$ \\
\hline 2003 & 85.254 & 623.800 & $7,268.245$ & $389,126.440$ & $53,181.445$ \\
\hline 2004 & 107.241 & 708.891 & $11,500.632$ & $502,526.450$ & $76,022.180$ \\
\hline 2005 & 109.705 & 709.836 & $12,035.187$ & $503,867.147$ & $77,872.558$ \\
\hline 2006 & 81.626 & 723.096 & $6,662.804$ & $522,867.825$ & $59,023.434$ \\
\hline Total & $\mathbf{4 1 9 . 4 9 7}$ & $\mathbf{3 , 2 9 6 . 5 5 0}$ & $\mathbf{3 8 , 7 3 9 . 2 8 8}$ & $\mathbf{2 , 2 0 0 , 2 7 1 . 3 4 1}$ & $\mathbf{2 8 5 , 0 3 8 . 3 1 4}$ \\
\hline
\end{tabular}

From the above calculations, the value of the correlation coefficient ( $\mathrm{r}$ ) is positive at 0.87 . If referring to the guidelines for providing an interpretation of the correlation coefficient according to Sugiyono $(2004 ; 214)$, it means that the relationship between promotional costs and company sales results is very strong and positive. This indicates that in the company's operational activities, promotional expenses, whether there is an increase or a decrease, have a very strong effect on the increase or decrease in company sales.

\section{Coefficient of Determination}

To find out how much the contribution of the independent variable (promotion costs) to the dependent variable (company sales results) can be found by calculating the Determination Coefficient (Kp) or the coefficient of determination, with the formula:

$$
\begin{aligned}
& \mathrm{Kp}=\mathrm{r}^{2} * 100 \\
& =0.87^{2} * 100
\end{aligned}
$$

Vol: 2, Issue: 1

January/2021

https://ijbssrnet.com/index.php/ijbssr

DOI: http://dx.doi.org/10.47742/ijbssr.v2n1p3
$=75.69 \%$

The calculation shows that the contribution of promotional activities to the company's sales results is $75.69 \%$. This means that the contribution of promotional costs is very significant to the sales results of the company. Simultaneously, the remaining small portion of $24.31 \%$ is a contribution made by other factors in the marketing mix, namely, product, price, place or distribution, services, and others.

\section{Correlation Significance Test}

To determine the significance level of the relationship between promotional costs and sales results/company revenue, it can be seen by doing the t-test. The results of the t-test show that there is a strong relationship between promotional activities carried out by the company with the results of sales/company revenue, and the contribution of these promotional activities is quite significant in increasing sales results/company revenues.

Effect of Promotion Costs on Company Revenue Results

Table 6. Simple Linear Regression Calculations

\begin{tabular}{|c|c|c|c|c|c|c|}
\hline $\mathbf{X}$ & $\mathbf{Y}$ & $(\mathbf{X}-\mathbf{X})$ & $(\mathbf{Y Y})$ & $x^{2}$ & $y^{2}$ & x.y \\
\hline 35.671 & 530.927 & -48.228 & -128.383 & $2,325.979$ & $16,482.195$ & $6,191.707$ \\
\hline 85.254 & 623.800 & 1.355 & -35.510 & 1.835 & $1,260.960$ & -48.102 \\
\hline 107.241 & 708.891 & 23.342 & 49.581 & 544.830 & $2,458.276$ & $1,157.300$ \\
\hline 109.705 & 709.836 & 25.806 & 50.526 & 665.929 & $2,552.877$ & $1,303.854$ \\
\hline 81.626 & 723.096 & -2.273 & 63.786 & 5.168 & $4,068.654$ & -145.011 \\
\hline$\varepsilon \mathrm{X}$ & $\varepsilon \mathrm{Y}$ & $\sum \mathrm{x}$ & $\varepsilon \mathrm{y}$ & $\sum \mathrm{x}^{2}$ & $\varepsilon \mathrm{y}^{2}$ & $\varepsilon \mathrm{X} . \mathrm{Y}$ \\
\hline 419.497 & $3,296.550$ & 0.000 & 0.000 & $3,543.741$ & $26,822.961$ & $8,459.747$ \\
\hline $\begin{array}{c}\mathrm{X} \\
83.899\end{array}$ & $\begin{array}{c}\mathrm{Y} \\
659.310\end{array}$ & & & & & \\
\hline
\end{tabular}
Promotion Costs $(\mathrm{X})$ and Underwriting Income (Y)

From the above calculations, it is known that the t-count is 3.022. When compared with the t-table with an error rate of $5 \%$ or a confidence level of $95 \%$ and $\mathrm{DK}=3$, namely: 2.353 , it is concluded that the $\mathrm{t}$-count is greater than the t-table, which means that there is a strong and significant influence between promotional costs with sales proceeds.

\section{Conclusions and Suggestions}

The results of research conducted at PT Wahana Tata Insurance, related to the relationship between promotional costs and company sales results, the results of the Correlation Analysis show that there is a very strong and positive relationship between promotional costs and company sales results, the results of the
Determinant Coefficient Analysis show that the contribution of promotional costs is very significant to the sales results of the company, and from the Correlation Signification Test that examines the relationship between the promotion costs and the sales results, strong and significant results are obtained. And from the results of the Simple Linear Regression Analysis and the Regression Coefficient Signification Test shows that there is a strong and significant influence between promotion costs and sales results. Referring to the research and analysis results, it is suggested that the company be able to look at these conditions and provide a balanced portion of promotional activities if they want to increase sales results.

\section{References}

Buchari Alma, (2004), Manajemen Pemasaran dan Pemasaran Jasa, Bandung: CV. Alfabeta.

Kotler, Phillip., (2005). Principles of the Marketing $10^{\text {th }}$ edition. Upper Saddle River, New Jersey: Prentice Hall, Inc. John T. (1984). Principle and Practice of Insurance. Foxton, Cambridge. The Burlington Press (Cambridge) Limited. 


\section{International Journal of Business and Social Science Research}

Vol: 2, Issue: 1

January/2021

https://ijbssrnet.com/index.php/ijbssr DOI: http://dx.doi.org/10.47742/iibssr.v2n1p3

(C)The Institute of Academic Research and Publication

http://iarpnet.org/

Sugiyono (2004). Metode Penelitian Administrasi. Cet. 9. Bandung, Alfabeta.

Supranto, J (1993). Metode Riset. Ed. 5, Jakarta : Lembaga Penerbit Fakultas Ekonomi Universitas Indonesia.

Swastha DH, Basu dan Irawan. (1990). Manajemen Pemasaran Modern. Ed. 2., Cet. 4. Yogyakarta : Liberty.

Usmara, A. (2003). Implementasi Manajemen Stratejik: Kebijakan dan Proses. Cet. 1, Jogjakarta : Amara Books. 